\title{
Stavros RODOKANAKIS*
}

\section{THE DYNAMICS OF REGIONAL LABOUR MARKETS AND TRAINING PROGRAMMES: GREEK EVIDENCE}

\section{INTRODUCTION}

The importance of vocational training in the EU has grown in the last two decades in terms of both funds allocated and the number of participants in the training programmes. This is the situation, although there are doubts concerning its impact on the labour market prospects of those participating in the training courses.

In the case of Greece the role of the EU was catalytic in changing the whole area of training in the country. This is evident from the amounts spent on training activities from the end of the 1980s up to now, the numerous training agencies which have been established in order to be involved in the training process and the increasing numbers of trainees on the various training courses. However, as we shall see, this training 'revolution' in the Greek case was not accompanied by a real improvement in matching supply with demand or increasing people's chances of finding a job.

The aim of the paper is to study the impact that education and training programmes (apprenticeship, intra-firm training, continuing vocational trainingCVT, popular training) had on the labour market in the Greek Region of Attica, during the implementation of the CSF-1 (1989-1993). Namely, we try to see whether the educational level itself and participation in training programmes increased the chances of finding a job. The vocational training programmes of the CSF-1 in the region under examination started in March 1990 and ended in

\footnotetext{
* Stavros RODOKANAKIS, Department of Social and Policy Sciences, University of Bath, Claverton Down, Bath BA2 7AY, England, e-mail: srodo@rdfcm.gr or srodo2003@yahoo.gr
} 
March 1995. All training actions in Greece are co-financed by the EU funds, whereas during the examined time period Attica belonged to the Objective 1 of the EU Structural Funds.

The Region of Attica is the largest in Greece in terms of population and the biggest urban centre in the country, Athens, is situated in this region. We work first at regional level, second at the level of Athens Area, and third at the rest of urban, semi-urban and rural level.

The main questions to be answered are:

1. What are the social and demographic characteristics that increase the chances of someone in the examined population finding a job?

2. How does the participation in training courses affect the chances of finding employment?

3. Whether University graduates, in contrast to most of the rest of the EU member states, face greater difficulties in finding a job than the non-University graduates, as a series of studies (see Meghir et al., 1989; OECD, 1990; Iliades, 1995; IN.E./GSEE-ADEDY, 1999; Katsikas, 2005) or statistics (Eurostat, 1995) for Greece conclude.

We test the human capital theory, which underpins many of the important developments in modern economics and provides one of the main explanations for wage and salary differentials by age and occupation, and the uneven incidence of unemployment by skill (education and training). We try to research whether the more educated and the more trained a person is, the higher the probability of him finding a job.

The importance of this research lies in the fact that, to the author's knowledge, it is the first time that the analysis of investigating the impact of training on the labour market of Attica is based on the micro-data of the Greek LFS. This is because access to the individual anonymised records of the Greek LFS was not allowed to researchers until the summer of 2005, due to the Data Protection Act.

The article starts with the issue of over-education and why it is important to this research. Then, we examine the impact of training programmes on the employment prospects of individuals in the EU and the rest of the OECD according to a series of studies; the results are based on both cross-sectional and longitudinal data. We discuss the vocational training policies for the unemployed in Greece. Finally, we refer to the socio-economic characteristics of the examined region and follow a logistic regression for the years 1988 and 1992 - based on micro-data of the Greek LFS - for the region under study. The article concludes with the impact of training on employment probability in Europe and the examined area, and ends with some general comments on the merit and value of this study. 


\section{WHY IS OVER-EDUCATION IMPORTANT TO THIS RESEARCH?}

According to the OECD (1990, p. 67, table 2.3), in Greece - contrary to what happens in many other European countries - the unemployment rate of university graduates was higher than that of the less educated, whilst, mainly since the late 1980s, a lot of graduates of tertiary education, especially of certain old traditional specialisations, faced problems of absorption into the labour market (Iliades, 1995). Also, according to Katsikas (2005) the University graduates in Greece face greater difficulties finding a job in comparison to the less educated. Meghir et al. (1989) analysed the main determinants of female participation in the labour force and male unemployment duration in Greece using data from the 1981 Greek LFS. An interesting finding is that male unemployment duration increased with education. Also, according to the study of IN.E./GSEE-ADEDY (1999), based on the processing of ESYE (National Statistical Service of Greece) aggregated data, the probability of an unemployed person becoming long-term unemployed depends on his/her age, gender and family status. Contrary to the common perception, this probability did not depend on the educational level.

Greek farming and especially Greek industry mainly consisted small businesses of traditional activities, which did not require administrative and technical staff with higher education and specialisation (Kanellopoulos, 1984). Besides, the family character of many Greek businesses made their owners avoid hiring staff (including those with high qualifications) or implementing innovative ideas of high skilled people, with the result that industry was unable to create enough new positions for people with relatively high specialization and to be unable to absorb the increased number of graduates (Kanellopoulos, 1984). Exactly the opposite happened in the public sector, where many new positions were created to absorb unemployed graduates. Although this waiting (queuing for a public sector job) raised the apparent unemployment of graduates (see, e.g. Krueger and Summers, 1987, p. 44), some of them held temporary jobs, often in the concealed economy (Glytsos, 1990). Moreover, the public sector limits its action to essentially bureaucratic competence and activities or to the provision of non-exchangeable services internationally. Greece seems to manifest over-education by any of the criteria mentioned above. The relative remuneration of university graduates was decreasing through time, mainly because of their over-supply (Glytsos, 1990). (For the causes of graduate unemployment see Johnes et al., 1987; Sanyal, 1987; Dolton and Vignoles, 2000). 


\section{THE HUMAN CAPITAL APPROACH AND THE HUMAN CAPITAL THEORY}

During the late 1950s and early 1960s the current neoclassical theory of the labour market emerged with the development of the human capital theory. Gary Becker $(1964,1975)$ published a book entitled 'Human Capital' which developed a theory of human capital formation and analysed the rate of return on investment in education and training. However, investment in human capital remains a controversial issue (Woodhall, 1987).

Whilst the human capital literature has highlighted a number of productivityrelated characteristics, human capital theorists give most emphasis to the importance of education and training as the main component of productivity (Blaug, 1975). Education, it is suggested, provides the basic skills of reading and writing, cognitive skills, and the 'ability to learn' which will increase an individual's productivity in all jobs (general human capital), whilst vocational education, on the other hand, will increase an individual's productivity in a narrower range of jobs by providing more specific skills (specific human capital).

Becker (1962) distinguishes general from specific human capital of workers, and within specific human capital between employer- and employee-financed on-the-job training. Most broadly the theory of specific human capital predicts that where the fixed costs of employment, due to on-the-job training, are greatest, unemployment is lowest (Rees, 1973, pp.118-120).

Following Becker's (1964) analysis on the economic role of human capital, particularly education, there is now a considerable amount of empirical research on the closely related topics of education and skills (see Prais, 1995; Murray and Steedman, 1998) and, more specifically, the increasing role of skilled labour in the economy (Berman et al., 1994; Machin, 1996; Green et al., 1998; Machin and van Reenen, 1998).

\section{UNEMPLOYMENT AND SKILLS IN GREECE AND THE REST OF THE EU}

It has been found in almost all EU and other countries that there is an inverse relationship between the level of education and training on the one hand and unemployment rates on the other. The reasons are the processes of screening and credentialism, but also the assumed higher productivity of better qualified people. Apparently employers not only associate higher skills with specific performance capabilities, but also with the social and flexible competences increasingly required in the course of technical progress (CEDEFOP, 1998). 
Data on unemployment and qualifications showed deviations with regard to different countries and national data sources, which cannot be presented here in detail. A comparison of statistics from different sources should be done very carefully. Thus, for example, Eurostat relates unemployment rates to the 25-59 years old, and OECD to people between 25 and 64 years of age. ${ }^{1}$

Table 1 gives unemployment rates by qualification in different EU countries according to Eurostat data. The differences were enormous. There are only a few countries where this inverse relation between unemployment and qualification did not exist: in Greece and Portugal unemployment among people on ISCED (International Standard Classification of Education) 3 level (Lyceum) was higher than among the less qualified, but not among the University graduates (ISCED 5-7); in Italy and Luxembourg, unemployment rates among the highly qualified (ISCED $5-7$, University) exceeded those of people with intermediate qualifications.

Table 1. Unemployment rates by level of educational attainment (25-59 years old); EU 1994

\begin{tabular}{|l|c|c|c|}
\hline \multicolumn{1}{|c|}{ Country } & ${\text { ISCED } 0-2^{*}}^{*}$ & ${\text { ISCED } 3^{* *}}^{\text {ISCED } 5-7^{* * *}}$ \\
\hline BEL & 12.5 & 7.5 & 3.7 \\
\hline DEN & 12.6 & 8.3 & 4.6 \\
\hline GER & 14.8 & 8.9 & 5.3 \\
\hline GRE & 6.2 & 8.3 & 5.3 \\
\hline ESP & 22.4 & 20.0 & 15.1 \\
\hline FRA & 14.8 & 9.7 & 6.6 \\
\hline IRL & 21.0 & 9.1 & 5.3 \\
\hline ITA & 9.3 & 7.4 & 8.1 \\
\hline LUX & 3.7 & 1.9 & 2.4 \\
\hline NL & 12.6 & 7.7 & 5.5 \\
\hline POR & 6.1 & 6.4 & 2.4 \\
\hline UK & 11.2 & 7.9 & 4.1 \\
\hline EU-12 & 13.2 & 8.8 & 6.1 \\
\hline
\end{tabular}

* ISCED 0-1: no qualifications. ISCED 2: 1 or more O-level/ GCSE passes, 1 or more CSE passes. All other qualifications.

** 1 or more A-level passes, GNVQ 3 and equivalent, NVQ 3 and equivalent. Trade apprenticeship. GNVQ 2 or equivalent, NVQ2 or equivalent.

${ }^{* * * *}$ All first and higher degrees. All teaching, nursing qualifications. HNC/HND.

Source: Eurostat (1995).

\footnotetext{
${ }^{1}$ In addition there are different definitions of educational attainment. Eurostat (in: Education across the EU, 1996) has defined a combined variable 'education and training level achieved' based on two questions in the LFS (question for attained general level of education, and for attainment of vocational or university training), whereas OECD refers to the conventional ISCED nomenclature.
} 
Looking at the long-term unemployment (LTU) of different skill levels, we again find that intermediate and higher educated people were less affected. This is true for the whole Union except Spain and Greece, where LTU was higher on ISCED levels 3 and 5-7 compared to levels $0-2$, for Italy where LTU was the highest on ISCED 3 level, and for Luxembourg and Portugal where the ratios of ISCED levels 0-2 and 3 were equal (Eurostat, 1995).

\section{IMPACT OF TRAINING AT MICRO-ECONOMIC LEVEL}

The early European evaluation studies are mostly characterised by the fact that research was not based on longitudinal and non-experimental data, as is the norm in the second generation studies (see section 5.2), but on cross-sectional and (quasi) experimental data. Experimental evaluations are common in the US but scarce in Europe (Bjorklund and Regner, 1996). The micro-economic studies on active labour market policies (ALMPs) were effectively summed up in OECD (1993a) and Fay (1996). Regarding training the basic conclusion was a frequently weak return to the training of the unemployed. In the majority of cases the most significant force decreasing the return was deadweight (i.e. a trained job-hunter is taken on but would have been employed in any case without training) - (Jackman et al., 1996). Heckman et al. (1999) and Stanley et al. (1999) concluded that if there were any positive treatment effects, concerning ALMP effectiveness in the US, then they would be negligible.

\subsection{The Findings from European Training and ALMP Evaluations (First Generation Studies)}

Among the ALMPs the greatest advance has been in the evaluation of training programmes, whilst the majority of training studies focused on the impact of training on future remuneration or on the likelihood of re-employment. The impact on the duration of the following employment period, too, has just been examined in studies done lately (e.g. Kaitz, 1979; Ridder, 1986; Card and Sullivan, 1988; Ham and Lalonde, 1991; Gritz, 1993; Bonnal et al., 1994; Torp, 1994; Zweimuller and Winter-Ebmer, 1996) - it is important to separate the length of employment from the duration of job tenure (Cockx et al., 1998).

In view of the growing differences in remuneration and employment possibilities between workers with skills and those without, it could be supposed that 
training schemes would give a high return to those involved in them. Hardly any support for this opinion is to be found in the micro-economic evidence on usual training programmes for unemployed adults, however unexpected this uniform result might be. Examination of accessible micro studies forces us to realize that it has been remarkably difficult to be clear about the foreseeable positive impact on those taking part (Jackman, 1995). It could be thought more extraordinary, according to Calmfors and Skedinger (1995), in view of the powerful theoretical points suggesting a positive impact when programmes were concentrated on a set of outsiders like these, that there is no more definite evidence on the impacts of centreing on the young.

A large number of different sorts of training programmes and their impacts were studied by OECD (1993a). In general it was found that programmes aimed at a few people only whose requirements are easily recognisable and at quite a high cost per person, frequently seemed to succeed relatively well in improving the remuneration and job possibilities of a number of the participants (this might account for the fact that training programmes in Norway, which were not that large, seemed to have succeeded much more effectively than in Sweden - Calmfors, 1995). In contrast, wider programmes involving more participants at quite a low cost per person normally appeared to make almost no difference (if any) to the prospects of those involved (Jackman, 1995). According to Rosholm and Skipper (2003) training raises the unemployment rate of participants but this effect disappears over time and this would indicate a locking-in effect.

These findings can be explained in different ways. One is that the characteristics of the unemployed differ to a great extent and taking into account their age, education and occupational backgrounds, just a few were able to gain from more training. Therefore, the only training programmes that had economic returns were those aimed at particular groups. Another explanation is that due to greater returns to training, only programmes with large inputs, i.e. targeted programmes, succeed. For instance, this could apply where the trainees are not used to the kind of skills they are learning, or for those not used to gaining skills by formal means (Jackman, 1995).

A number of evaluations have involved employer surveys or other means aimed at revealing how far job-hunters will be touched by replacement. There is, though, not much evidence to hand concerning particular extra side-effects like production moving to other businesses or earnings changes. Information on replacement and movement effects on production concerning those people not taking part is minimal (OECD, 1993a).

It follows that a labour market policy desirous of putting all unemployed people on a programme or giving them temporary work, cannot be largely made up of effective training programmes (OECD, 1993b; Calmfors, 1994). 


\subsection{Findings from Recent European Programme Evaluation on Training and ALMPs (Second Generation Studies)}

To judge the impact of programmes, the majority of the ALMP studies examine treatment impacts on either employment (unemployment) figures or length of employment (unemployment) or risks. A few studies (Bell et al., 1999; Larsson, 2000; Lechner, 2000; Raaum and Torp, 2002; Regner, 2002) also view earnings as outcome variables worthy of attention. Regarding evaluation techniques, the majority of studies use matching estimators. These try to copy a randomized experiment ex post because of a plethora of non-experimental data.

In contrast to the early European evaluation studies - cited in section 5.1 cross-sectional data is hardly to be found and training research in Europe has replaced it with the more useful longitudinal data, allowing for the possibility that impact assessments will be more robust (Kluve and Schmidt, 2002). Namely, the studies of section 5.2 examined the same population groups over time, apart from those of Winter-Ebmer (2006) and Cueto and Mato (2009) which used only one reference year in their research; also, only one study (that of Malmberg-Heimonen and Vuori, 2005) used experimental data.

These results show that the more expensive programmes having a significant amount of training appear to be most effective at increasing employment prospects (see Kluve et al., 1999; Brodaty et al., 2001; van Ours, 2001; Kluve and Schmidt, 2002; Raaum and Torp, 2002). Lately, national studies do not all find positive impacts (Gerfin and Lechner, 2000; Regner, 2002); but bearing in mind that job creation and subsidies for employment in the public sector usually do not succeed (Kluve et al., 1999; Brodaty et al., 2001), especially if their one aim is to remove unemployed people from the register (Lechner, 2000), training seems to have a significant impact.

Concerning the most recent research (Weber and Hofer, 2003; Centeno et al., 2004 - on earnings as well; Graversen, 2004; Graversen and Jensen, 2004; Hujer et al., 2004; Rosholm and Svarer, 2004; Hogelund and Holm, 2005; Aakvik and Dahl, 2006), there is no impact of training on employment probability in the European labour markets. Also, according to a series of studies (Lechner et al., 2005 - on earnings as well; Malmberg-Heimonen and Vuori, 2005; Steiger, 2005; Lechner et al., 2007 - on earnings as well; Cueto and Mato, 2009 a locking-in effect of trainees is shown that it may be decreasing labour mobility) the employment effects of training are mixed, namely there are positive and negative results. Furthermore, recent research on Europe has also found that training has positive effects on employment probability, although in some cases more for specific age groups or areas (Cockx, 2003; Hamalainen and Ollikainen, 2004; Leetmaa and Vork, 2004; Albrecht et al., 2005 - for young men on employment effects; research on earnings as well, but no impact on income effects; Arellano, 2005 - higher positive effects for women than for men; 
Cavaco et al., 2005; Fitzenberger and Speckesser, 2005 - more in West Germany than in East Germany; Kluve et al., 2005; Lorentzen and Dahl, 2005 - but modest effects and only on earnings; Stenberg, 2005; Winter-Ebmer, 2006 - for men and on earnings as well; Mato and Cueto, 2008 - but no effects on earnings).

Kluve and Schmidt (2002) assert that in view of the fact that Heckman et al. (1999) did not discover a reliable pattern arising from the first generation of European studies, the provisional results - that employment subsidies are less effective than training and that public sector programmes are not as good as private sector ones - help to explain ALMP impacts in Europe. The above authors stress that the findings of their basic quantitative perquisition should be viewed tentatively, they successfully link earlier results on European evaluation research to more up-to-date findings and provide a new explanation for ALMPs' impact in Europe. If nothing else, their analysis shows that (1) training and help with job-hunting are capable of being worthwhile, (2) it is not easy to help the youth and (3) previous evaluation findings were too hopeful. Also, according to them, in spite of the fact that a number of the specific evaluation characteristics - the stress on youth schemes, or the concentration on employment as opposed to remuneration - are discernably European in nature, European programmes are relatively diverse.

In conclusion, up-to-date evaluation studies point to minor impacts of European training policies and they are most likely less significant and not always as positive as those responsible for designing them had wished. Although the crossnational figures show a few positive results from programmes, it is impossible to disregard the more negative results. The findings allow us to conclude that training programmes seem to have some positive effects on employment and no effects on earnings. Moreover, effects diminish over time. The negative effects reported by several evaluations can be explained, on the one hand by a lockingin effect, and on the other by the fact that some participants seem to enrol in training merely in order to collect unemployment insurance benefits (Cueto and Mato, 2009). The conclusions based on the recent studies are somewhat similar to those of Heckman et al. (1999) and Stanley et al. (1999) for the US.

The point here is not to give the impression that the one correct supplier of evidence concerning micro-economic impacts are quantitative impact evaluations. It must be noted that the effect of active policies might be incorrectly presented by micro-economic evaluations, because, due to unnoticed diversity, the real impact of a programme on those taking part might not be counted. Different types of information may have their uses, such as official policy studies, research in various professional fields, and different kinds of administrative monitoring data. Figures revealing the percentages of previous scheme participants who found employment after finishing the programmes are frequently published by governments. However, on the whole, this is not enough to estimate effects (OECD, 1993a). 


\section{VOCATIONAL TRAINING POLICIES FOR THE UNEMPLOYED IN GREECE}

The structure of expenditures for 'active' interventions in 1997 shows that the level of expenditures in Greece $(0.35 \%)$, as a percentage of the GDP, is behind that of the EU-15 average (1.13\%) concerning all specific interventions, with the exception of 'measures for the young' (youth vocational education and training etc. $-0.10 \%)$ which are comparable to the European average $(0.13 \%)$. Furthermore, there is an extremely low level of expenditures on the training of adults (0.06\% for Greece in comparison to $0.29 \%$ for the EU-15) - (OECD, 1999).

The system of CVT in Greece was developed mainly due to its incorporation in Community funding programmes (Iliades, 1995; Chletsos, 1998; Papakonstantinou, 1998). Policies concerned with training and retraining for the unemployed have been confined to continuing training programmes. Vocational training programmes for the unemployed were wholly unconnected with employment policies, and were thus wasteful of training resources (Gravaris, 1991, p. 37; Christodoulakis and Kalyvitis, 1995; Balourdos and Chryssakis, 1998). This is reflected in the fact that the unemployment rate for those (20-29 years old) with complementary vocational training in Greece was $20 \%$, compared to $14 \%$ for those with only compulsory schooling; the corresponding figures for the EU were $11.5 \%$ and 23.5\% (Economic and Social Committee of Greece, 1998, p. 31).

Particularly with regard to training programmes for the unemployed in Greece, the method of identifying skills requirements, on the basis of which the programmes were offered, was wholly inadequate. It was based on changes in labour force categories derived from the LFS, on estimates of the impact of investment programmes on employment (where these existed or where such estimates were possible) and on Job Market Surveys. These last record shortages of skills on the basis of company estimates of their own shortages, which were often inaccurate or did not correspond to the capacity of the firms to utilise the skills demanded (Linardos-Rylmon, 1998).

\section{THE REGION OF ATTICA}

The Region of Attica (NUTS-2 and Objective 1 status during the CSF-1) which is geographically situated in Central Greece - is the county of Attica and consists of four prefectures (Attica or Athens, Eastern Attica, Western Attica and Piraeus). The above region is the one and only region-county in Greece, since according to 1991 census its population size was about 3.5 million inhabitants; namely, 3 out of 10 Greeks lived in Attica. The capital of the region is the city of 
Athens, which is by far the most important Greek city in economic, administrative and political terms.

In 1988, Attica's GDP was equal to $61 \%$ of the EU-12 average (58\% for Greece as a whole), whereas in 1996 the region improved its position since its GDP was $77 \%$ of the EU-15 mean (68\% for the country as a whole) and $86 \%$ of the EU-25 mean in 2003 (80.9\% for Greece as a whole). In 2003, Attica was ranked third among the 13 Greek regions, based on that criterion (GDP per capita), after Central Greece and the Southern Aegean. The Region of Attica produces $37.4 \%$ of the country's GDP $-2.7 \%$ of the country's agricultural produce, $35.5 \%$ of the manufacturing and $42 \%$ of services (2001) - (sources: www.ypes.gr/attiki and www.economics.gr).

There was an increase in the percentage of unemployed from $10 \%$ in 1988 to $11.7 \%$ of the workforce in $1995 .^{2}$ The male unemployment rate was $6.47 \%$ in 1988 and $8.4 \%$ in 1995 , whereas the corresponding female percentages were $16.32 \%$ and $16.86 \%$. LTU - as percentage of total unemployment - amounted to $45.4 \%$ in 1988 and $50.9 \%$ in 1995 (LFS).

\section{NUMBERS OF RECORDS IN THE LFS SAMPLES}

The questionnaire of the European (and Greek) LFS was greatly modified in 1992 (Felstead et al., 1998). The originality of this research is that we use individual anonymised records (micro-data) of the LFS for both employed and unemployed (about 53,000 records per year for Attica, namely $1.5 \%$ of the total population of the region).

Table 2 shows the numbers of employed, unemployed and non-active in the LFS samples (in the spring, namely from the 14th to 26th week of the year) of the region under examination in 1988 and 1992.

Table 2. Labour force and non-active population in Attica (LFS samples)

\begin{tabular}{|c|c|c|c|c|c|}
\hline Year & Employed & Unemployed & Non-active & System missing & Total \\
\hline 1988 & 18,166 & 2,023 & 23,580 & 9,886 & 53,655 \\
\hline 1992 & 18,465 & 2,158 & 24,338 & 8,265 & 53,226 \\
\hline
\end{tabular}

Apart from the system missing records, following the limitation of age (1564 years old) and removing the non-active population, we ended with the following numbers of records eligible for analysis (table 3 ).

\footnotetext{
${ }^{2}$ The percentage of unemployment is characterised by an augmentative tendency with the exception of the two year period 1989-1990, during which it shows a temporary decrease.
} 
Table 3. Numbers of records eligible for analysis

\begin{tabular}{|c|c|c|}
\hline Year & Region & No. of records \\
\hline 1988 & Attica & 19,922 \\
\hline 1992 & Attica & 20,301 \\
\hline
\end{tabular}

\section{THE LOGISTIC REGRESSION BASED ON THE MICRO-DATA OF THE GREEK LFS}

The basic aim of the econometric analysis is to test the impact that training programmes (apprenticeship, intra-firm training, CVT, popular training) and educational level had on people's job prospects in the Region of Attica, during the implementation of the CSF-1 (1989-1993), accounting for demographic characteristics such as age, gender, marital status and area of residence. We try to see whether participation in training programmes and educational level increased the chances of finding a job. In the paper, we use a logistic regression model for studying differences between those that did participate in training programmes and those that did not. Regression models allow for group comparisons adjusting for demographic and socio-economic variables. It should be noted that regression-adjusted comparisons may still provide misleading results when other important variables that might have an effect are omitted.

The dependent variable takes two possible values (employed versus unemployed). The explanatory variables (six for 1992 and five for 1988) are the participation in training courses (only available in 1992 with five categories including the four types of training completed, as mentioned above, and nonparticipation in training courses as the reference category), six levels of education, gender, age level (four categories), marital status and residence location (Athens Area, the rest of urban areas, semi-urban areas and rural areas).

The effect of demographic variables such as age, gender, marital status, residence location, as well as educational level and participation in training programmes on the employment status, is investigated with a logistic regression model due to the categorical nature of the dependent variable. The logistic regression model is written as:

$$
\operatorname{logit} P\left(y=1 \mid x_{1}, \ldots, x_{k}\right)=\log \left[\frac{P\left(y=1 \mid x_{1}, \ldots, x_{k}\right)}{1-P\left(y=1 \mid x_{1}, \ldots, x_{k}\right)}\right]=\beta_{0}+\sum_{k=1}^{K} \beta_{k} x_{k} \text {, }
$$


where $P\left(y=1 \mid x_{1}, \ldots, x_{k}\right)$ and $1-P\left(y=1 \mid x_{1}, \ldots, x_{k}\right)$ denote the conditional probability a randomly selected individual to be 'unemployed' and 'employed' respectively. The coefficient $\beta_{k}$ denotes the effect that a unit increase in the explanatory variable $x_{k}$ has on the log odds of being 'unemployed' than 'employed' controlling for all other variables in the model and $\beta_{0}$ is the intercept of the model and the value of the logit when all the explanatory variables take the value zero. More specifically, a unit increase in the explanatory variable $x_{k}$ multiplies the odds by $e^{\beta_{k}}$ controlling for all other variables in the model.

Solving the above formula with respect to the conditional probability we have:

$$
P\left(y=1 \mid x_{1}, \ldots, x_{k}\right)=\frac{e^{\beta_{0}+\sum_{k=1}^{K} \beta_{k} x_{k}}}{1+e^{\beta_{0}+\sum_{k=1}^{K} \beta_{k} x_{k}}} .
$$

Due to data limitations, we cannot explore the impact that the duration of courses, thematic fields, number of participants, duration of unemployment period of the trainees have on unemployment. Another limitation of the research is that the data available are cross-sectional rather than longitudinal and therefore we cannot study any population changes across time. The Greek LFS data are non-experimental.

\subsection{Description of the Variables}

We define now the complete list of variables together with their coding values that we use in the model.

Dependent variable. Employment Status $(\mathrm{STA} 1)$ (Unemployed = 1, Employed $=0$ ).

Explanatory variables. The reference category of each variable is underlined.

1) Gender (STA 2) $($ Female $=1$, Male $=0)$

2) Marital status (STA 3) (Married, divorced or widows $=1$, Non-married $=0$ )

3) Level of education (STA8A-STA8D)

STA $8 \mathrm{~A}=$ University graduates

STA $8 \mathrm{~A} 1=$ MSc or PhD holders

STA $8 \mathrm{~B}=$ Polytechnic $(\mathrm{TEI})$ graduates

STA $8 C=$ Lyceum graduates (12 years of schooling) or not finished University

STA $8 \mathrm{C} 1=$ High-school graduates $(9$ years-compulsory education) 
STA 8D = Primary school graduates or not finished primary school or never in school

4) Urbanisation level of settlement system (STA9A-STA9E)

STA 9A = Athens Area

STA 9C $=$ Rest of urban areas

STA 9D $=$ Semi-urban areas

STA 9E $=$ Rural areas

5) Participation in the past in training course(s) (STA26A-STA26E)

STA 26A = apprenticeship

STA $26 \mathrm{~B}=$ intra-firm training

STA $26 \mathrm{C}=$ continuing vocational training $(\mathrm{CVT})$

STA $26 \mathrm{D}=$ popular training

STA 26E = Non-participation in the past in training course(s)

6) Age groups (STA40A-STA40E)

STA $40 A=15-24$ years old

STA $40 \mathrm{D}=25-34$ years old

STA $40 \mathrm{E}=35-44$ years old

STA $40 \mathrm{C}=45-64$ years old

The base (or reference) categories are those that appear in the table 3 with empty cells and with which the rest of the corresponding variables are compared. The reference categories are chosen so as to match the needs of the research.

We have excluded the 14 and 65 year olds in order to avoid including in our analysis those who are younger than 14 and older than 65 years old.

The variable 'participation in the past in training course(s)' first appeared in the 1992 questionnaire; it means that the interviewee had completed one or more training courses. This is also an indication of the attitude towards training in Greece at the end of the 1980s. The duration of apprenticeship and intra-firm training had to be at least one year according to the questionnaire of the Greek LFS. The term 'popular training' (laiki epimorphosi in Greek) means training courses intended mainly for elderly people independently of their educational level, where the curriculum includes largely courses of general knowledge.

\subsection{Results for Attica}

Table 3 gives the results of logistic regression in Attica. For 1988 and 1992, women, non-married individuals, and young people (15-24 years old) were more likely to be unemployed than men, married individuals and people in older age groups. The gender differences could be attributed to the fact that women often join the labour market earlier. Compulsory military service and further 
education (not a likely explanation anymore) were the major reasons for men's delay in entering the labour market. Extended family protection, with a view to preparation for entry into the labour market, applies to both sexes, of course.

Table 3. Results for Attica, 1988 and 1992 (parameter estimates $b_{k}$, standard errors (s.e.), $p$-value, exponent of $b_{k}$ )

\begin{tabular}{|l|c|c|c|c|c|c|c|c|}
\hline \multirow{2}{*}{\multicolumn{1}{|c}{ Variables }} & \multicolumn{5}{|c|}{1988} & \multicolumn{4}{c|}{1992} \\
\cline { 2 - 10 } & $b_{k}$ & s.e. & $p$-value & $\operatorname{Exp}\left(b_{k}\right)$ & $b_{k}$ & s.e. & $p$-value & Exp $\left(b_{k}\right)$ \\
\hline Gender & 0.81 & 0.05 & 0.000 & 2.24 & 0.92 & 0.05 & 0.000 & 2.50 \\
\hline Marital status & -0.68 & 0.06 & 0.000 & 0.51 & -0.55 & 0.06 & 0.000 & 0.58 \\
\hline Aged 15-24 & ----- & ----- & ------ & ------- & ----- & ----- & ------ & ------- \\
\hline Aged 25-34 & -0.93 & 0.07 & 0.000 & 0.40 & -0.90 & 0.07 & 0.000 & 0.41 \\
\hline Aged 35-44 & -1.40 & 0.09 & 0.000 & 0.25 & -1.37 & 0.09 & 0.000 & 0.25 \\
\hline Aged 45-64 & -1.62 & 0.10 & 0.000 & 0.20 & -1.48 & 0.09 & 0.000 & 0.23 \\
\hline University graduates & ----- & ----- & ----- & ------ & ----- & ----- & ----- & ------ \\
\hline MSc or PhD holders & -0.42 & 0.30 & 0.154 & 0.66 & 0.54 & 0.31 & 0.081 & 1.71 \\
\hline TEI graduates & -0.10 & 0.09 & 0.279 & 0.91 & 0.15 & 0.11 & 0.162 & 1.17 \\
\hline 12 years of schooling & 0.02 & 0.07 & 0.813 & 1.02 & 0.32 & 0.08 & 0.000 & 1.38 \\
\hline $\begin{array}{l}\text { 9 years-compulsory } \\
\text { education }\end{array}$ & 0.02 & 0.09 & 0.801 & 1.02 & 0.41 & 0.10 & 0.000 & 1.51 \\
\hline $\begin{array}{l}\text { Primary school } \\
\text { graduates and below }\end{array}$ & 0.05 & 0.08 & 0.496 & 1.06 & 0.67 & 0.08 & 0.000 & 1.95 \\
\hline Athens Area & 0.89 & 0.31 & 0.004 & 2.42 & 0.18 & 0.24 & 0.445 & 1.20 \\
\hline Rest of urban areas & 0.82 & 0.33 & 0.013 & 2.26 & 0.39 & 0.26 & 0.133 & 1.47 \\
\hline Semi-urban areas & 0.29 & 0.35 & 0.414 & 1.33 & 0.23 & 0.26 & 0.380 & 1.26 \\
\hline Rural areas & ----- & ----- & ------ & ----- & ----- & ----- & ------ & ------ \\
\hline Apprenticeship & NA & NA & NA & NA & -0.23 & 0.37 & 0.543 & 0.80 \\
\hline Intra-firm training & NA & NA & NA & NA & -18.7 & $* * *$ & 0.999 & 0.00 \\
\hline CVT & NA & NA & NA & NA & 0.47 & 0.46 & 0.310 & 1.60 \\
\hline Popular training & NA & NA & NA & NA & -18.2 & $* * *$ & 0.999 & 0.00 \\
\hline $\begin{array}{l}\text { Non-participation in } \\
\text { the past in training } \\
\text { course(s) }\end{array}$ & NA & NA & NA & NA & ----- & ----- & ----- & ------ \\
\hline Constant & -2.03 & 0.31 & 0.000 & 0.13 & -1.85 & 0.25 & 0.000 & 0.16 \\
\hline
\end{tabular}

*** standard errors are large and not reported.

In 1988, education was not found to be statistically significant. On the contrary, for 1992 university graduates were more likely to be employed compared to Lyceum, high school and primary school graduates. Those results are in 
contrast to some studies which assert the opposite (see section 1). Also in the Region of Attica, all training variables were found to be statistically nonsignificant; this means that the results of training variables are not compatible with the human capital theory, so the more trained a person did not affect his chances of finding a job, in Attica, during the time period of the CSF-1. The same results on training were found for other Greek regions as well (see Rodokanakis and Tryfonidis, 2008; Rodokanakis, 2009; Rodokanakis and Tryfonidis, 2009). Also, the results of the logistic regression confirm the conclusions of the various studies for the limited impact of vocational training in Greece (see section 6).

In 1988, people who lived in the Athens Area or in the rest of urban areas were more likely to be unemployed than people in rural areas. One reason may be the fact that in the Greek agrarian sector unemployment was not properly counted. Living in semi-urban areas was not found statistically significant. In 1992, all categories of the urbanisation variables were found non-significant. This seems reasonable for Attica, since - as we have already mentioned - Attica is the only county-region in Greece, so, in Attica, the meaning of semi-urban and rural areas is very relevant.

\subsection{Quantifying the Effect of Explanatory Variables}

From table 3, it is clear that the estimated odds of being unemployed show greater differences at the levels of the variables 'gender' and 'urbanisation' rather than the rest of the demographic variables with the exception of the variable urbanisation in the Region of Attica in 1992. For example, in 1988 and 1992 in Attica, the estimated odds that a woman is unemployed are 2.24 and 2.50 times respectively the estimated odds for a man at any given level of marital status, educational and urbanisation level, age group and type of training completed.

In Attica in 1988, the estimated odds show a $142 \%$ increase in the estimated odds in Athens and 126\% increase in the rest of urban areas than in rural areas. No significance differences were found in 1992 in Attica.

In Attica in 1992, the estimated odds for Lyceum graduates, high-school and primary school graduates are 1.38, 1.51 and 1.95 times the estimated odds for university graduates indicating a $38 \%, 51 \%$ and $95 \%$ respectively increase in the estimated odds for unemployed.

Finally, in Attica both in 1988 and in 1992, the estimated odds of people in the three age groups $25-34,35-44$ and 45-64 imply a decrease in the estimated odds compared to the 15-24 years old group. 


\subsection{Interaction Effect among Variables}

Only for the 1992 sample did we fit the interaction effects between training and urbanisation level, and between training and level of education. Interactions terms were not found to be statistically significant in Attica. Therefore, the variable 'training' does not alter the relationship between unemployment and education, as well as unemployment and urbanisation level. In other words, the chances of finding a job do not change when we count training as an additional qualification in relation to residence location and level of education.

\section{CONCLUSIONS}

A significant number of researchers making use of accessible data and studies to examine the potential impacts of training on employment have been referred to. In spite of being restricted to only a small number of nations, micro-economic studies of effect evaluations indicate that some programmes have managed to noticeably better employment prospects for those taking part. On the other hand, the findings include a number of programmes which appear to have had almost no effect.

Programmes with fairly specific targeting have brought positive results and this may be due to the fact that these programmes usually take account of individual requirements. However, a number of programmes that were most widely targeted have had little impact. Lastly, to establish the ways in which programmes can be made better more research is necessary.

According to the findings of our logistic regression, the results for gender, marital status and age groups are the same for 1988 and 1992. Namely, women were more likely to be unemployed than men, the married were less likely to be unemployed than the non-married, whereas people in the age group 15-24 years old were found in a worse situation in the labour market in relation to the remaining age categories.

The level of education is statistically non-significant for 1988. This result is probably related to the fact that the 1988 LFS questionnaire is less detailed concerning questions on education than the corresponding one in 1992. In 1992, the University graduates in Attica were in a better position in the labour market than the primary school, high-school or lyceum graduates. Also, in both years, whether or not someone had a degree from TEI (Polytechnic) or had a Master or $\mathrm{PhD}$ is statistically non-significant.

All training variables are statistically non-significant for 1992 (as already mentioned in section 9, we cannot explore training in 1988 due to the limitations 
of data); so, the results of the logistic regression confirm the conclusions of the various studies for the limited or non impact of vocational training in Greece (see section 6). Given the population size of the examined region, we could conclude the same for the entire country. The results of the interaction effect analysis show again that training is statistically non-significant in relation to both urbanisation level and educational level.

Finally, regarding the urbanisation level of the settlement system, although in 1992 the residence location was not important (statistically non-significant) in Attica, in 1988 this was true only for semi-urban areas; in the other two cases (Athens Area and the rest of urban areas) people who lived there were in a worse situation as regards finding a job in comparison to those living in rural areas. Concerning the residence location in the case of Attica in 1988 there were some reservations which may be related to the fact that the 1992 LFS data are better than those of 1988, as the most recent data are better than those of 1992 . Consequently the investigation of the subsequent years is needed in order to have a clearer picture of the 1990s given the fact that, as mentioned in the introduction, the Greek LFS micro-data are now available to researchers.

The research would merit attention of a wider international readership, since the paper does offer results that are useful for comparative research among European capital regions and European regions in general. Also, the study will be valuable to those who are interested in designing and implementing training programmes for structural change investigating the deficiencies and inefficiencies which have occurred in the Greek case.

\section{REFERENCES}

AAKVIK, A. and DAHL, S. (2006), 'Transitions to Employment from Labour Market Enterprises in Norway', International Journal of Social Welfare, 15 (2), pp. 121-30.

ALBRECHT, J., BERG, G. J. van den and VROMAN, S. (2005), 'The Knowledge Lift: The Swedish Adult Education Program that Aimed to Eliminate Low Worker Skill Levels', IZA Discussion Paper 1503, Bonn.

AREllanO, F. A. (2005), 'Do Training Programmes Get the Unemployed Back to Work? A Look at the Spanish Experience', Working Paper, 05-25, Economics Series 15, Universidad Carlos III de Madrid.

BALOURDOS, D. and CHRYSSAKIS, M. (1998), 'Programmes of Continuing Vocational Training: Statistical Indications, Evaluation and Perspectives' (in Greek), [in:] MARATOUALIPRANTI, L. and HATZIGIANNI, A. (eds), Unemployment, Employment, Educationtraining in Greece and France. Proceedings of the Franco-Hellenic Colloquium, Athens, EKKE, pp. 133-50.

BECKER, G. S. (1962), 'Investment in Human Capital: A Theoretical Analysis', Journal of Political Economy, 70 (supplement), October, pp. 9-49.

BECKER, G. S. (1964), 'Human Capital', Columbia University Press, New York. 
BECKER, G. S. (1975), Human Capital: A Theoretical and Empirical Analysis with Special Reference to Education, New York: Columbia University Press.

BELL, B., BLUNDELL, R. and REENEN, J. van (1999), 'Getting the Unemployed Back to Work: The Role of Targeted Wage Subsidies', International Tax and Public Finance, 6 (3), pp. 339-360.

BERMAN, E., BOUND, J. and GRILICHES, Z. (1994), 'Changes in the Demand for Skilled Labor within US Manufacturing Industries: Evidence from the Annual Survey of Manufacturing', Quarterly Journal of Economics, CK, pp. 367-398.

BJORKLUND, A. and REGNER, H. (1996), 'Experimental Evaluation of European Labour Market Policy', [in:] SCHMID, G., O'REYLLY, J. and SCHOMANN, K. (eds), International Handbook of Labour Market Policy and Evaluation, Cheltenham: Edward Elgar.

BLAUG, M. (1975), 'The Empirical Status of Human Capital Theory', Journal of Economic Literature, 14, pp. 827-855.

BONNAL L., FOUGERE, D. and SERANDON, A. (1994), 'L'impact des dispositifs d'emploi sur le devenir des jeunes chomeurs: Une evaluation econometrique sur donaces longitudinales', Economie et Prevision, 115, pp. 1-28.

BRODATY, T., CREPON, B. and FOUGERE, D. (2001), 'Using Matching Estimators to Evaluate Alternative Youth Employment Programs: Evidence from France, 1986-1988, [in:] LECHNER, M. and PFEIFFER, F. (eds), Econometric Evaluation of Labour Market Policies, Heidelberg: Physica.

CALMFORS, L. (1994), 'Active Labour Market Policy and Unemployment: A Framework for the Analysis of Crucial Design Features' OECD Economic Studies, 22, spring, pp. 7-47.

CALMFORS, L. (1995), What Can we Expect from Active Labour Market Policy?, The Institute for International Economic Studies, Reprint Series, 546, University of Stockholm.

CALMFORS, L. and SKEDINGER, P. (1995), 'Does Active Labour-market Policy Increase Employment? Theoretical Considerations and Some Empirical Evidence from Sweden', $O x$ ford Review of Economic Policy, 11 (1), pp. 91-109.

CARD, D. and SULLIVAN, D. (1988), 'Measuring the Effect of Subsidized Training Programs on Movements in and out of Employment', Econometrica, 56, pp. 497-530.

CAVACO, S., FOUGERE, D. and POUGET, J. (2005), 'Estimating the Effect, of a Retraining Program for Displaced Workers on their Transition to Permanent Jobs', IZA Discussion Paper, 1513, Bonn.

CEDEFOP (1998), Socio-economic Framework of Vocational Education and Training, in Training for a Changing Society. A Report on Current Vocational Education and Training Research in Europe. Part II, Reference document, Thessaloniki, Brussels, Luxembourg, pp. 33-116.

CENTENO, L., CENTENO, M. and NOVO, A. A. (2005), Evaluating the Impact of a Mandatory Job Search Program: Evidence from a Large Longitudinal Data Set (mimeo).

CHLETSOS, M. (1998), 'The Education as an Active Employment Policy: Limits and Preconditions of Implementation. The Case of Greece' (in Greek), [in:] MARATOU-ALIPRANTI, L. and HATZIGIANNI, A. (eds), Unemployment, Employment, Education-training in Greece and France. Proceedings of the Franco-Hellenic Colloquium, Athens: EKKE, pp. 151-79.

CHRISTODOULAKIS, N. and KALYVITIS, S. (1995), 'Likely Effects of the CSF 1994-1999 on the Greek Economy', Discussion Paper, 46, KEPE, Athens.

COCKX, B. (2003), 'Vocational Training of Unemployed Workers in Belgium', Applied Economics Quarterly, 49 (1), pp. 23-48.

COCKX, B., LINDEN, B. van der and KARAA, A. (1998), 'Active Labour Market Policies and Job Tenure', Oxford Economic Papers, 50, pp. 685-708. 
CUETO, B. and MATO, F. J. (2009), 'A Non-experimental Evaluation of Training Programmes: Regional Evidence for Spain', The Annals of Regional Science, 43 (2), pp. 415-433.

DOLTON, P. and VIGNOLES, A. (2000), 'The Incidence and Effects of Over-education in the UK Graduate Labour Market', Economics of Education Review, 19 (2), pp. 179-198.

ECONOMIC AND SOCIAL COMMITTEE OF GREECE (1998), Opinion of Initiative for the 'Vocational Training', Athens, June (in Greek).

ESYE [National Statistical Service of Greece], (1988-2003), Statistical Yearbook and Labour Force Survey.

EUROSTAT (1995), Education and Employment Prospects.

EUROSTAT (1996), Education Across the EU.

FAY, R. (1996), 'Enhancing the Effectiveness of Active Labour Market Policies: Evidence from Programme Evaluations in OECD Countries', Labour Market and Social Policy, occasional papers, 18 , OECD, Paris.

FELSTEAD, A., GREEN, F. and MAYHEW, K. (1998), 'Interpreting Training Statistics in Europe: Issuing a Health Warning', European Journal of Vocational Training, 14, pp. 62-69.

FITZENBERGER, B. and SPECKESSER, S. (2005), Employment Effects of the Provision of Specific Professional Skills and Techniques in Germany, Department of Economics, GoetheUniversity Frankfurt (mimeo).

GERFIN, M. and LECHNER, M. (2000), 'Micro-econometric Evaluation of the Active Labour Market Policy in Switzerland', IZA Discussion Paper, 154, Bonn.

GLYTSOS, N. P. (1990), 'Modeling Future Higher Education-labour Market Imbalances: A Multi-scenario Approach', Economics of Education Review, 9 (1), pp. 1-23.

GRAVARIS, D. (1991), 'The Politico-economic Foundations of Employment Policies' (in Greek), Topos: Review of Urban and Regional Studies, 4, Athens.

GRAVERSEN, B. (2004), Employment Effects of Active Labor Market Programs: Do the Programs Help Welfare Benefit Recipients to Find Jobs?, PhD thesis, Department of Economics, University of Aarhus.

GRAVERSEN, B. and JENSEN, P. (2004), 'A Re-appraisal of the Virtues of Private Sector Employment Programs', chapter 3 [in:] GRAVERSEN, B.

GREEN, F., FELSTEAD, A. and GALLIE, D. (1998), 'Changing Skill-intensity: An Analysis Based on Job Characteristics', Working Paper.

GRITZ, M. R. (1993), 'The Impact of Training on the Frequency and Duration of Employment', Journal of Econometrics, 57 (1-3), pp. 21-52.

HAM, J. C. and LALONDE, R. J. (1991), 'Estimating the Effect of Training on Employment and Unemployment Durations: Evidence from Experimental Data', Working Paper, 3912, NBER, Cambridge, MA.

HÄMÄLÄINEN, K. and OLLIKAINEN, V. (2004), 'Differential Effects of Active Labor Market Programmes in the Early Stages of Young People's Unemployment', VATT Research Reports, 115, Helsinki.

HECKMAN, J. J., LaLONDE, R. J. and SMITH J. A. (1999), 'The Economics and Econometrics of Active Labour Market Programs', [in:] ASHENFELTER, O. and CARD, D. (eds), Handbook of Labor Economics, 3A, Amsterdam: Elsevier, pp. 1865-2097.

HOGELUND, J. and HOLM, A. (2005), 'Returning the Long-term Sick-listed to Work: The Efforts of Educational Measures and Employer Separations in Denmark', [in:] SAUNDERS, P. (ed.), Welfare to Work in Practice. Social Security and Participation in Economic and Social Life, International Studies on Social Security, 10, Ashgate: Aldershot.

HUJER, R., THOMSEN, S. and ZEISS, C. (2004), 'The Effects of Vocational Training Programmes on the Duration of Unemployment in Eastern Germany', IZA Discussion Paper, 1117, Bonn. 
ILIADES, N. (1995), Continuing Vocational Training in Greece, National Report (in the context of FORCE), National Institute of Labour, January (in Greek).

IN.E./GSEE [Institute of Labour/General Confederation of Workers of Greece] - ADEDY [Civil Servants' Supreme Administrative Council] (1999), The Greek Economy and the Employment, Annual Report, Reports 1, Athens, August (in Greek).

JACKMAN, R. (1995), 'What Can Active Labour Market Policy Do?', Discussion Paper, 226, CEP, LSE.

JACKMAN, R., LAYARD, R. and NICKELL, S. (1996), 'Combating Unemployment: Is Flexibility Enough?', Discussion Paper, 293, CEP, LSE.

JOHNES G., TAYLOR, J. and FERGUSON, G. (1987), 'The Employability of New Graduates: A Study of Differences between UK Universities', Applied Economics, 19, pp. 695-710.

KAITZ, H. B. (1979), 'Potential Use of Markov Process Models to Determine Program Impact, [in:] BLOCH, F. E. (ed.), Research in Labour Economics, Greenwich, CT: JAI Press.

KANELLOPOULOS, C. (1984), 'Education and Labour Market in Greece' (in Greek), [in:] Implications of Technological and Scientific Revolution, Athens: TEI, pp. 108-115.

KATSIKAS, Ch. (2005), Studies-Vocation and Labour Market, Atrapos (in Greek).

KLUVE, J. and SCHMIDT, C. M. (2002), 'Can Training and Employment Subsidies Combat European Unemployment?', Economic Policy: A European Forum, 35, October, pp. 411-448.

KLUVE, J., LEHMANN, H. and SCHMIDT, C. M. (1999), 'Active Labour Market Policies in Poland: Human Capital Enhancement, Stigmatization, or Benefit Churning?', Journal of Comparative Economics, 27 (1), pp. 61-89.

KLUVE, J., LEHMANN, H. and SCHMIDT, C. M. (2005), Disentangling Treatment Effects of Active Labor Market Policies: The role of Labor Force Status Sequences, RWI Essen (mimeo).

KRUEGER, A. B. and SUMMERS, L. H. (1987), 'Reflections on the Inter-industry Wage Structure', [in:] LANG, K. and LEONARD, J. (eds), Unemployment and the Structure of Labour Markets, Oxford: Basil Blackwell, pp. 17-47.

LARSSON, L. (2000), 'Evaluation of Swedish Youth Labour Market Programmes', Working Paper, 6, Department of Economics, Uppsala University.

LECHNER, M. (2000), 'An Evaluation of Public Sector Sponsored Continuous Vocational Training Programs in East Germany', Journal of Human Resources, 35, pp. 347-375.

LECHNER, M., MIQUEL, R. and WUNSCH, C. (2005), 'Long Run Effects of Public Sector Sponsored Training in West Germany', CEPR Discussion Paper, 4851.

LECHNER, M., MIQUEL, R. and WUNSCH, C. (2007), 'The Curse and Blessing of Training the Unemployed in a Changing Economy: The Case of East Germany After Unification', German Economic Review, 8, November, pp. 468-509.

LEETMAA, R. and VÖRK, A. (2004), Evaluation of Active Labor Market Programmes in Estonia, PRAXIS Tallinn (mimeo).

LINARDOS-RYLMON, P. (1998), 'Vocational Training and Labour Market: Indispensable Changes into the Function of the Continuing Training System in Greece' (in Greek), [in:] MARATOU-ALIPRANTI, L. and HATZIGIANNI, A. (eds), Unemployment, Employment, Education-training in Greece and France. Proceedings of the Franco-Hellenic Colloquium, Athens: EKKE, pp. 233-236.

LORENTZEN, T. and DAHL, E. (2005), 'Active Labour Market Programmes in Norway: Are They Helpful for Social Assistance Recipients?', International Journal of Social Welfare, 14 (2), pp. 86-98.

MACHIN, S. (1996), 'Wage Inequality in the UK', Oxford Review of Economic Policy, 12, pp. $47-64$. 
MACHIN, S. and van REENEN, J. (1998), 'Technology and Changes in Skill Structure: Evidence from Seven OECD Countries', The Quarterly Journal of Economics, November, pp. 12151244.

MALMBERG-HEIMONEN, I. and VUORI, J. (2005), 'Activation or Discouragement - The Effect of Enforced Participation on the Success of Job-search Training', European Journal of Social Work, 8 (4), pp. 451-467.

MATO, F. J. and CUETO, B. (2008), 'Un análisis de los effectos de las politicas de formación a desempleados', Revista de Economia Aplicada http://www.revecap.com/revista/aceptados/ matocueto.pdf (in press).

MEGHIR, C., IOANNIDES, Y. and PISSARIDES, C. (1989), 'Female Participation and Male Unemployment Duration in Greece, European Economic Review, 33, pp. 395-406.

MURRAY, A. and STEEDMAN, H. (1998), 'Growing Skills in Europe: The Changing Skills Profiles of France, Germany, the Netherlands, Portugal, Sweden and the UK', TSER, Discussion Paper, 399, CEP, LSE.

OECD (1990), Employment Outlook, Paris.

OECD (1993a), 'Active Labour Market Policies: Assessing Macro-economic and Micro-economic Effects', Employment Outlook, ch. 2, Paris, pp. 39-80.

OECD (1993b), Employment Outlook, Paris.

OECD (1999), Employment Outlook, Paris.

OURS, J. C. van (2001), 'Do Active Labour Market Policies Help Unemployed Workers to Find and Keep Regular Jobs?, [in:] LECHNER, M. and PFEIFFER, F. (eds), Econometric Evaluation of Labour Market Policies, Heidelberg: Physica.

PAPAKONSTANTINOU, G. (1998), 'Education-training as Factors of Investment in Human Capital' (in Greek), [in:] MARATOU-ALIPRANTI, L. and HATZIGIANNI, A. (eds), Unemployment, Employment, Education-training in Greece and France. Proceedings of the FrancoHellenic Colloquium, Athens: EKKE, pp. 125-132.

PRAIS, S. J. (1995), Productivity, Education and Training: An International Perspective, National Institute for Economic and Social Research, Cambridge University Press.

RAAUM, O. and TORP, H. (2002), 'Labour Market Training in Norway: Effect on Earnings', Labour Economics, 9 (2), pp. 207-247.

REES, A. (1973), The Economics of Work and Pay, New York: Harper and Row.

REGNER, H. (2002), A Non-experimental Evaluation of Training Programmes for the Unemployed in Sweden, Labour Economics.

RIDDER, G. (1986), 'An Event History Approach to the Evaluation of Training, Recruitment and Employment Programmes', Journal of Applied Econometrics, 11, pp. 109-126.

RODOKANAKIS, S. (2009), 'Investigating the Unemployment Risk in Greece from the LFS Individual Anonymised Records: The Case of Central Macedonia', The Empirical Economics Letters, 8 (1), pp. 35-43.

RODOKANAKIS, S. and TRYFONIDIS, D. (2008), 'The Probability of Being Unemployed in the Three Northern Greek Regions during the CSF-1: Econometric Analysis of the LFS Microdata', Journal of European Economy, 7, special issue (following a selection of papers presented at the International Conference on Applied Economics (ICOAE) 2008, Kastoria, Greece, 15-17 May), pp. 332-347.

RODOKANAKIS, S. and TRYFONIDIS, D. (2009), 'Unemployment Hazard in the Aegean Islands: Econometric Analysis of the LFS micro-data', [in:] BROX, J. A. and BALTAS, N. (eds), The Global Economics of a Changing Environment, chapter 14, Waterloo: North Waterloo Academic Press, pp. 211-224.

ROSHOLM, M. and SKIPPER, L. (2003), 'Is Labour Market Training a Curse for the Unemployed? Evidence from a Social Experiment', IZA Discussion Paper, 716, Bonn. 
ROSHOLM, M. and SVARER, M. (2004), 'Estimating the Threat Effect of Active Labor Market Programs', Working Paper, 6, Department of Economics, University of Aarhus.

SANYAL, B. C. (1987), 'Graduate Unemployment and Education', [in:] PSACHAROPOULOS, G. (ed.), Economics of Education: Research and Studies. Part IV: Education and Employment, Pergamon Press, pp. 172-179.

STANLEY, M., KATZ, L. and KRUEGER, A. B. (1999), Impacts of Employment and Training Programs: The American Experience, Harvard University (mimeo).

STEIGER, H. (2005), Is Less More? A Look at Non-participation in Swiss Active Labor Market Programmes, University of St. Gallen (mimeo).

STENBERG, A. (2005), 'Comprehensive Education for the Unemployed - Evaluating the Effects on Unemployment of the Adult Education Initiative in Sweden', Labour, 19, pp. 123-146.

TORP, H. (1994), 'The Impact of Training on Employment: Assessing a Norwegian Labour Market Programme', Scandinavian Journal of Economics, 96, pp. 531-550.

WEBER, A. and HOFER, H. (2003), 'Active Job-search Programs a Promising Tool? A Microeconometric Evaluation for Austria', IHS Working Paper, Economic Series, 131, Vienna.

WINTER-EBMER, R. (2006), 'Coping with a Structural Crisis: Evaluating an Innovative Redundancy-retraining Project', International Journal of Manpower, 27 (8), pp. 700-721.

WOODHALL, M. (1987), 'Economics of Education: A Review', [in:] PSACHAROPOULOS, G. (ed.), Economics of Education: Research and Studies, Pergamon Press, pp. 1-8.

www.economics.gr

www.ypes.gr/attiki

ZWEIMULLER, J. and WINTER-EBMER, R. (1996), 'Manpower Training Programmes and Employment Stability', Economica, 63 (249), pp. 113-130. 